\title{
Az érzelmek szerepe a szerencsejátékokban és a függőség kialakulásában
}

\section{The role of emotions in the gambling}

\subsection{6/recreation.2012.2.4.1}

Alábbi dolgozat a szerencsejáték szenvedély kialakulásának érzelmi oldalát, ezen belül az izgalom szerepét igyekszik kideríteni.

Szinte triviális, hogy a legtöbb szerencsejáték esetén késedelem van a fogadás és annak kimenetele között, de az ebből adódó várakozás épphogy csökkenti a függőség kialakulásának kockázatát (Griffiths, 1999). Az emberek várakozásaiból fakadó pozitív és negatív érzések szerepet játszanak viselkedésükben. Loewenstein 1987-ben vizsgálta és kimutatta, hogy a negatív és pozitív kimenetel vonatkozásában eltérően viselkednek az emberek (Loewenstein, 1987.) A kimenetel előtti szakaszban a tapasztalt feszültségtől, illetve kellemes izgalom mértékétől függ a késleltetés preferált foka. Barkan és Busemeyer 2003-as, valamint E. B. Andrade és G. Iyer 2007-es kísérletei előtt Becker és Murphy már 1988-ban publikálták, hogy a szerencsejátékos tevékenység egyik legfontosabb motívuma az izgalom. Kutatásaim is azt igazolták, hogy a nyerési vágy mellett a játék jellegéből adódó „kellemes feszültség” miatt játszanak az emberek. Dolgozatomban a fent említett „izgalmas” kísérletek bemutatását követően a szerencsejáték függők ebbéli kéröíves eredményeit ismertetem.

\section{Kulcsszavak: szerencsejáték, játékszenvedély, izgalom, unalom}

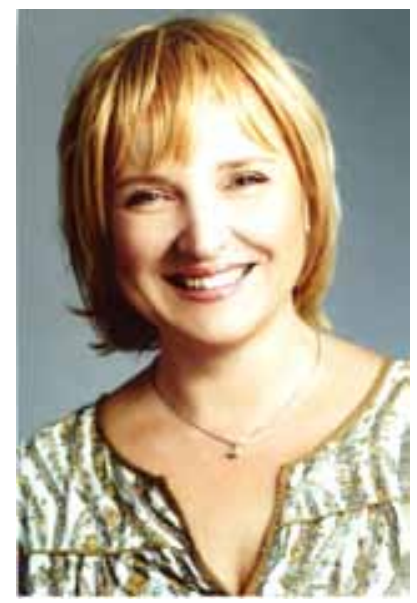

Szerző:

TESSÉNYI JUDIT

Szerencsejáték Zrt.

Szeged, Szilléri sgt. 31-33.

doktorjelölt

szerencsejáték szenvedély festés

\section{BEVEZETÉS}

A szerencsejáték tevékenységhez, mint gazdasági tevékenységhez számos alap illetve összetett érzelem kapcsolható. Különösen érdekes ez, ha a szerencsejátékot szenvedéllyel, azaz problémásan üzők gazdasági viselkedését szeretnénk megérteni. Mind a prevenció, mind pedig a konkrét kezelés vonatkozásában lényeges annak feltérképezése, hogy melyek azok az attitűdök, motivációs szempontok, és kiváltott érzelmek, amelyek ezt a fajta magatartást érthetővé teszik. „A pszichológiai vonal a közgazdaságtanban hiányos egy fontos területen: Elhanyagolja az érzelmek hatását az emberi viselkedésben. Az érzelmi eljárások vizsgálata sokáig még a pszichológiában is csak kisebb szerepet játszott. Csak az utóbbi évtizedben került az érzelmek elemzése egyre több 


\section{ㄱill}

Abstract:

In the most gambling activity there is a delay on betting and outcome. However anticipation caused by this delay reduces the risk of addiction. The positive and the negative feelings caused by the anticipation can be built in the people's utility function. In 1987 Loewenstein showed that people has different patience to the negative and positive outcome (Loewenstein, 1987). In the period before the outcome, the delay's degree of preference depends on the tension and the pleasant excitement.

Economists and psychologist have recognized the joyful expectation in the majority of gambling (Griffiths, 2000,2007). Before Barkan and Busemeyer experiment in 2003 and E.B. Andrare and G. Iyer experiment in 2007 Becker and Murphy showed that the most important motivator of gambling is excitement. My researches also showed that people gamble because of the desire to win but the good stress caused by the nature of gambling is the other important reason. In my essay after the above mentioned exciting experiments I show the result of the gambling addicts questionaire in this subject. A lot of basic and complex emotions can be linked to the gambling activity as an economic activity. This is particularly relevant if we want to understand the economic behaviour of the players who gamble with passion, so who are problem gamblers. Related to the prevention and the particular treatment it is essential to explore which attitudes, motivational aspects and evoked emotions make this kind of behaviour understandable. In economic aspects researchers found out later that the role of emotions is very important in the decision making.

\section{Keywords: gambling, gambling addiction, anxiety, boredom}

pszichológus látóterébe; részben az ideggyógyászattal való halvány kapcsolata miatt." (Fehr, 2005). Gazdasági vonatkozásban még későbbre datálhatjuk az érzelmek szerepének beemelését a döntéshozatali folyamat megértéséhez.

\section{KORÁBBI GAZDASÁGPSZICHOLÓGIAI KUTATÁSI EREDMÉNYEK AZ ÉRZELMEK VONATKOZÁSÁBAN}

A döntéseinkben tapasztalható idöbeli következetlenségek (dinamikus inkonzisztenciák) vizsgálatának egyik mérföldköve az önkontroll és a türelmetlenség beépítése a közgazdasági modellekbe. Míg számos kísérlet azt igazolta, hogy „jobb ma egy veréb, mint holnap egy túzok", addig Loewenstein és társai kimutatták, hogy az örömteli várakozás adott esetekben felülírhatja ezt a közvélekedést. „Amikor a várakozás maga kellemes izgalmat okoz, olyankor hajlandóak vagyunk a jutalmakat önként elhalasztani. Nemcsak az idő hossza és a jutalom nagysága, hanem az idői mintázat is növeli vagy csökkenti a jutalom értékét. Az olyan idői mintázatot preferáljuk, amikor a jutalom folyamatosan növekszik." (Faragó, 2003.) Ezzel magyarázhatjuk, hogy a jelen élvezetei felértékelődnek a jövő perspektivikus céljai és lehetőségei előtt.

Az időinkonzisztens diszkontálás és az önkontrollproblémák mint a dinamikus inkonzisztenciák két eltérő okára Matthew Rabin hívta fel a figyelmet a Kivetítési torzítás a jövőbeli hasznosságok elörejelzésében című esszéjében: „Érdemes a két jelenséget röviden megkülönböztetnünk, különösen mivel mindkettő előidézheti a dinamikus inkonzisztenciát. ... az emberek az azonnali szükséglet kielégítésre vonatkozóan időinkonzisztens ízléssel rendelkeznek. ... Azonosak lehetnek a kettőnek a pszichológiai megerösítései is, mivel mindkettő tartalmazza azt a hibát, hogy az emberek rosszul ítélik meg jelenlegi és jövőbeli érzéseik eltéréseit. A dinamikus inkonzisztencia két oka azonban elkülöníthető aszerint, hogy mi a hibás előrejelzés tárgya: míg a kivetítési torzítás a jövőbeli azonnali hasznosságok hibás előrejelzése, addig a naivitásból fakadó önkontrollproblémák a jövőbeli azonnali hasznosságokhoz kapcsolódó relatív súlyok hibás előrejelzését jelentik." (Rabin, 2003. 221.o.) A kivetítési torzítások modellezésének - fent hivatkozott dolgozatában - éppen a lottó-játékosok motivációjának, majd nyertesként történő magatartás változásának miértjeire keresi a szerző a választ.

Griffiths és Wood Európa szerte (Hollandia, Egyesült Királyság, Spanyolország, Svédország, Finnország, Csehország és Németország) kutatták a szerencsejáték szenvedély okait, attitűdjeit és a kormányzati szabályozás szerepét. Úgy találták, hogy a játékok földrajzi (fizikai) elérhetősége, az állami szabályozás, a felvilágosítás mind-mind befolyással lehet az egyes szerencsejátékok veszélyességének mérséklésére, amelyek meglátásuk szerint termék-fajtánként és életkoronként is jelentősen eltérőek. Vizsgálatuk egyértelmű következtetése, hogy az intenzitás meghatározó a függőség kialakulása szempontjából, azaz ha nem kell várni a sorsolásra és a nyereményre (pl.: kaparós sorsjegyek) a problémássá váló szerencsejáték sokkal valószínübb (Griffiths és Wood, 2000). 
Későbbi kutató munkájukban feltárták, hogy az érzelmileg fogékony játékos könnyebben válik problémássá, ide értve a labilis lelki állapotú, szuicid hajlamú, egyéb szerfüggő és a hangulatzavarban szenvedő játékosokat. Az érzelmi elem a problémás szerencsejátékosoknál érzékelt fokozott izgalom, és az „érzéseik elöli menekülés”, szemben a normális játékosokéval. Vizsgált problémás játékosaik is nagyobb valószínüséggel számolnak be különböző disszociációról, de megállapításuk szerint az, hogy a problémás játékosok mindegyike érzelmileg zavart ez még nem jelent ok-okozati összefüggést, csak „másodlagos-motiváció” (Griffiths és Wood, 2007). Viszont az általuk is hivatkozott Ricketts és Macaskill vizsgálata (2003.), mely kismintás szerencsejáték függők körében folytattak, egyértelmüen az érzelmek szerepét találta meghatározónak a függők esetén.

A Szegedi Tudományegyetem Közgazdaságtani Doktori Iskola Gazdaságpszichológia Kutató Mühelyében az önkontroll szerepét vizsgálata Lippai László friss disszertációja (Lippai, 2011), melyben szintén találkozhatunk konkrét szerencsejátékos (kaparós sorsjegyes) kutatással. Ő az önkontroll szempontjából vizsgálta a fogyasztók döntéseit az egészségükkel, a fogyasztásuk késleltetésével és bizonyos gazdaságpolitikai alternatívák véleményezésével kapcsolatban. Továbbá, kvalitatív információk gyűjtésével arra tett kísérletet, hogy azonosítson a fogyasztók preferenciarendszerének hátterében álló motívumokat.

\section{IZGALMI SZINTEK, DEFINÍCIÓK}

Csak megemlítve azokat az elméleti vitákat, melyek az izgalmat nem is érzelemként, illetve nem alapérzelemként tartják számon - mondván, hogy minden érzelem része az izgalom -, és az érzelmek kategorizálásának szerteágazó szakirodalmát - vizsgálatunk szempontjából az izgalom jelentőségére koncentrálunk.

Az izgalom „valamely esemény okozta feszült, nyugtalan idegállapot; Biológiai szervben, szövetben fokozott vagy rendszertelen müködésben megnyilvánuló kóros állapot” (Magyar Értelmező Kéziszótár, 1987.). Hipotézisünk szerint a nyerési vágy mellett meghatározó, kiemelt jelentősége van az izgalomnak, ebben az értelemben az unalomüzés az az elsődleges motivációs szempont, mely a szerencsejátékra - alább mért eseteiben pedig - a túlzott szerencsejátékra ösztönöz.

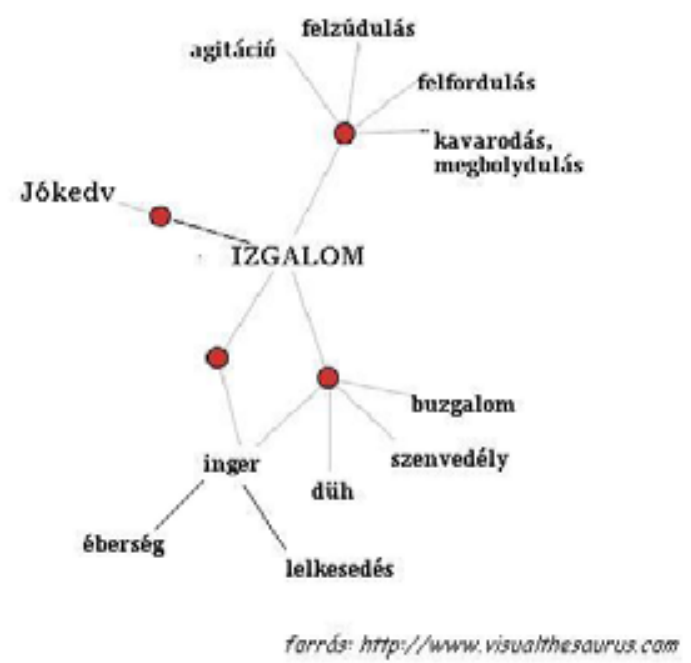

1.szimú ảbra: Az izgalon verbảlis „.kōrüllhatirolása”

1.számú ábra: Az izgalom verbális „körülhatárolása”

Az izgalom definiálása számos irányból megközelíthető, a dolgozat szempontjából a továbbiakban azon érzelmi állapotot értjük alatta, mely befolyásolja a fogyasztó preferencia sorrendjét (preferenciarendszerét) és jóléti függvényeit. $A$ viselkedés megértéséhez az érzelmek és ezen belül az izgalom vizsgálatán keresztül is vezethet egy út. A szerencsejáték szenvedély gazdaságpszichológiai aspektusú vizsgálata során eljuthatunk annak felismeréséhez, hogy a problémás viselkedés az izgalmasság megélése és lereagálása szempontjából is eltér a normál szerencsejátékosétól. Míg egy örömteli játék (várakozás) esetén a „felfokozott hangulat” és a „lelkesedés” a problémamentes játékosnál rövid és „kellemes”, addig a játékszenvedély betegeknél inkább az izgatottság és a stressz elemei meghatározóak. Az érzelmi intenzitás, szenzoros élménykeresés és a motiváltság Gray-féle megközelítése alapján a szenvedélyes szerencsejáték a következményeket figyelmen kívül hagyó, impulzív viselkedésben fejeződik ki (a személy az intenzív élmények hajszolása során nincs tekintettel a társas konvenciókra).

A személyiségi tényezők, úgymint az impulzivitás, megküzdési stratégiák vagy az antiszociális magatartás szerepet játszanak a szerencsejáték szenvedély kialakulásában (Sinha, 2004.). Az impulzivitás szintje mindkét nemnél fontos tényező a kóros játékszenvedély kialakulása szempontjából. A férfiaknál azonban gyakrabban találunk impulzív élménykeresőt a problémás szerencsejátékosok között, a nőkhöz képest. Mindkét nemnél az impulzivitás erős kiinduló oka a lehetséges szerencsejáték problémáknak (Nower, Derevensky, és Gupta, 2004). A szerencsejáték szenvedély betegek esetén mindkét nemben magas az impulzivitás és az élménykeresés (Sinha, 2004.). Az 
impulzus kontroll zavarban szenvedőknél a stressz szintén fokozhatja a már meglévő problémás szerencsejátékot (Lightsey \& Hulsey, 2002).

Az impulzivitás és az élménykeresés korrelációját a szerencsejáték szenvedély kialakulásával Zuckerman és McDaniel mutatta ki 2003-ban.

\section{AZ IZGALOM, MINT JÁTÉK-MOTIVÁCIÓS TÉNYE- ZÖ}

1986-ban publikálta Blaszczynski szerzőtársaival azon kísérleti eredményét, mely a szerencsejátékosok és játékszenvedély betegek körében végzett vizsgálatuk alapján az endorfin szerepét igyekezett kimutatni. Az eredmények azt mutatták, hogy a vizsgált patológiás szerencsejátékosok nem különböztek kiindulási B-endorfin szintjükben a kontrollcsoporttól. De különbséget találtak a szerencsejáték típusok szerint: kiderült, hogy a lóverseny-függők jelentősen alacsonyabb kiindulási szintűek, mint a póker-géppel játszók és a kontrolcsoport (Blaszczynski és munkatársai, 1986.).

A következő évben Dickerson és szerzőtársai interjúk és kérdőív segítségével a kockázatkerülés és szorongás vonatkozásában vizsgálták a szerencsejátékos magatartást. Azt találták, hogy a játékszenvedélyes viselkedés központi eleme az önkontroll kikapcsolása (megszűnése) és szignifikáns kapcsolatot mutattak ki az élménykeresés és az unalom-érzékenység alskálákon. Az érzelmi skálán feltárt egyéni különbségek a nagyobb összegű veszteségekre adott reakciók és a problémássá válható szerencsejátékos viselkedés közti kapcsolatra hívták fel a figyelmet (Dickerson et al. 1987.).

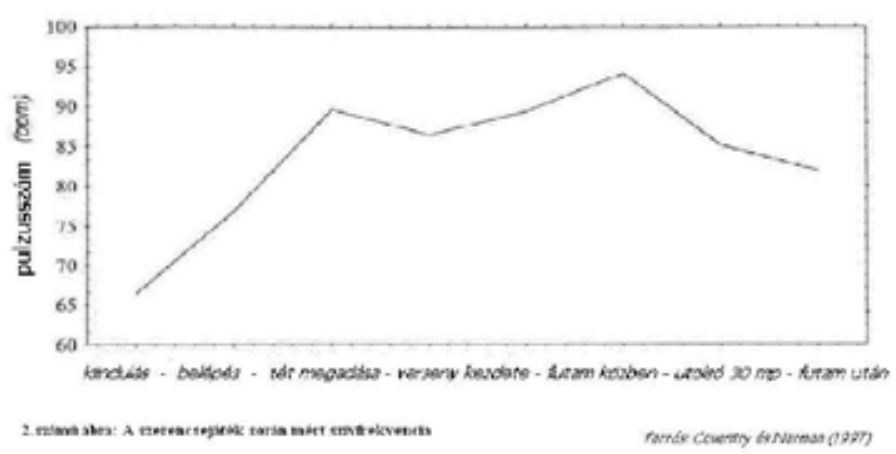

2.számú ábra: A szerencsejáték során mért szívfrekvencia

Az MRI, CT, PET mérések mellett jól bevált módja az érzelmek mérésének is a szívfrekvencia rögzítése. Ennek példáját láthatjuk Normannék '97-es mérési adatainál az 1-es számú ábrán, melyen látható, hogy játék közben jelentősen megnő az izgalmi szint - amennyiben ezt a jelenséget a szívritmussal kívánjuk mérni, sőt a játék befejezését követő időszakban - 30 percben is még magasabb a normálisnál .

Különbséget találtunk a normál játszók, és a szenvedélyes szerencsejátékosok viselkedése közben, amelynek gazdasági vonatkozásban az lehet a jelentősége, ha ezeket a problémás játékosokat akár az értékesítőhelyeken, akár Internetes játé- kaik során sikerül megfelelő paraméterek - úgymint az izgalom - mentén beazonosítani, akkor „a nem kívánatos játék” ki is szürhető.

„Az idegtudományi felfedezések alapján, a „szív” és „ész”, vagy az „érzelem” és „kognitív döntések” az egyénre vonatkoznak - a közgazdászok által alkotott modellekbe nem helyettesíthetőek be (Loewenstein és O'Donoghue 2004, Fudenberg és Levine 2005). Ezek a modellek azért vonzóak mégis, mert összhangban állnak hatalmas számú pszichológiai eredménnyel a viselkedésröl, amit nem tud megmagyarázni a hagyományos gazdasági modell. Ezen felül, ezek a modellek matematikailag jól kezelhetőek, könnyebb az alkalmazhatóságuk sok gazdasági kapcsolatban... jó példái annak, hogy az idegtudományi felfedezések hogyan szolgálhatják a gazdasági kutatás." (Fehr, 2005)

Bíztatóak annak a magyar kutatócsoportnak az eredményei is, akik az agy CB1 receptorainak kutatása terén az idegrendszer mélyszerkezetének feltárásával jónéhány neurológiai és pszichiátriai betegség megértéséhez keresi a kulcsot (Freund T., 2007.):

„A függőségben is lényeges a tanulás: az anyag hatására hirtelen jött eufóriát tanulja meg az agy az adott szerrel, annak beviteli módjával, és a társuló külső körülményekkel összekötni. Fontos, hogy a váratlanul jött ,jutalom” sokkal gyorsabb és tartósabb tanulást eredményez, mint az elvárt és megérdemelt. Ennek az lehet az értelme, illetve evolúciós haszna, hogy ha például egy állat adott helyen váratlanul bőséges táplálékforrást fedez fel, az ide vezető útvonalat azonnal megjegyezze. Ugyanezen agyi rendszer azonban nem tesz különbséget váratlan és váratlan között, és ezáltal a függőséghez vezető útvonalat is „kikövezi”. Embernél ez lehet az alapja nemcsak a drog-, alkohol-, stb., hanem akár a szerencsejáték-függőségnek is: az arra hajlamosaknál elég egy váratlan nyeremény, hogy a személy újra és újra próbálkozzon, akár a csődbe menésig is." (in. Jakabffy, 2009.)

A szerencsejáték-szervezés mind az állami játékszervező, mind az üzleti érintettek (stakeholderek), mind pedig a játékosok vonatkozásában egy prosperáló üzleti magatartásként, tevékenységként is felfogható, kivéve hogyha ennek a személyes, szociális vagy társadalmi költségei már olyan jelentősek, melyek az ebből származó hasznot akár az egyén, akár a társadalom szintjén ellensúlyozzák.

\footnotetext{
${ }^{1}$ Itt hivatkozott vizsgálatukba 54 föt vontak be, s bár eredeti hipotéziseiket nem sikerült alátámasztaniuk, de a mérési eredményeik mégis tanulságosak. A fenti táblázatban a kísérletben részt vevő 54 fő átlagértékeit láthatjuk. Két évvel később publikált kutatásukkor (ezt már nem Normannal, hanem Constable-val jegyzi, lásd. 2.b ábra) 32 játékautomatával játszó nő szívfrekvencia méréseit rögzítették - a szerencsejáték eltérő fázisai alatt ( $p<0,01$, szórás a játék alatt 0,65 , a játék után 0,73 ).

${ }^{2}$ saját fordítás
} 


\section{GENERÁCIÓS KÜLÖNBSÉGEK}

Az izgalom keresése, a kockázatkereső magatartás nem csak személyiségfüggő, hanem életkori sajátosságokkal is bír. A szerencsejáték szenvedélyes korcsoportok közül két markánsan körülírható csoport rajzolódott ki az eddigi kutatási eredmények alapján:

A pervazív zavarok a játékosra, a családtagra és a társadalomra is hatással vannak. Például $12-24 \%$ a kóros szerencsejátékosok körében az öngyilkossági kísérlet. A naponta 6 óránál többet a számítógép előtt töltő, tipikusan a 20 év alatti, otthon is gépet használók köréböl kerülnek ki az Internet-függők. A „fiatal férfi szindróma” pl. a kockázat-kereső magatartásban teljesedik ki (Hoyer, 2011.), mely nem csak az alkohol- és drogfogyasztás, de a hozzájuk gyakran társuló kóros szerencsejátékos magatartásban is megnyilvánul.

Jonatan Parker és szerzőtársai (2000) már több mint 10 éve kutatják a generációs különbségeket elsősorban a serdülökorúak vonatkozásában. Valamennyi játéktípusra külön-külön lefolytatott vizsgálatuk avval a konklúzióval zárul, hogy elsősorban a serdülö 15 év körüli fiúk a legveszélyeztetettebb korcsoport, nemcsak a hagyományos szerencsejátékok, hanem az Internetes játékok, illetve az Internetes szerencsejátékok vonatkozásában is.

Mimi Larsson 2003-as empirikus vizsgálata az idősebbek bekapcsolódását kutatta az információs és kommunikációs technológiák gyakorlati alkalmazásában:

„A felmérés során adott válaszaikat tekintve úgy tünik, hogy a „lassú kezdőknek” mindenekelőtt jó okra van szükségük ahhoz, hogy idejüket és pénzüket valamire fordítsák. Úgy tünik, hogy sem a technikai „mütyürkékkel” való játék öröme vagy izgalma, sem a digitális tudásgazdaság homályos víziója nem nyújt elegendő motivációt számukra."(Larsson, 2003) A már korábban hivatkozott '87-es Dickerson kísérlet is kimutatta, hogy az unalom is szerepet játszhat egyes kóros tevékenységek folytatásában vagy kialakításában. Ez a veszély különösen fenyegeti a nyugdíjas korúakat, illetve az aktív munkás életszakaszukat lezárókat, akiknek önálló szegmensként való megjelenésére először az amerikai kutatók hívták fel a figyelmet az un. Las Vegas-jelenség kapcsán.

\section{MÓDSZEREK}

2011 során 239 önkéntes személy töltötte ki a gambler anonimus (továbbiakban GA) 20-as tesztjét, mely a szerencsejáték szenvedélyesség szürését szolgálja (Gamblers Anonymus, 1984). A kitöltés önállóan, önkéntesen és névtelenség biztosításával történt.

A kutatás eredeti célja a szerencsejáték forgalmazáshoz szükséges gépkezelői tanfolyamra jelentkezők szürése volt (hogy olyanok ne válhassanak értékesítőivé, akik esetleg maguk problémásak). Az összegyűjtött adatok, kérdőívek és információk azonban lehetőséget biztosítottak az alább részletezett szekunder vizsgálatra, illetve értékelésre is.

Ezen tesztsor kérdései között találunk néhány kérdést, amely kimondottan az érzelmekkel kapcsolatos (1.számú mellék- let). Ilyen például a 15. amelyik arra keresi a választ, hogy az aggodalmak és gondok elöl fordult-e a megkérdezett a szerencsejátékokhoz, illetve zavarta-e például az alvását, vagy a 18-as kérdés, amely a veszekedések, csalódások vagy a feszültség miatti játékokra kérdeznek rá. A megkérdezett 239 tesztelt közül 8,8 \% a GA szürötesztjén is fennakad, azaz problémás vagy veszélyeztetett kategóriába tartozik. Ennek a saját kutatásnak az adatait láthatjuk a 3-as számú ábrán, részletezett adatait pedig a 2 . számú mellékletben. A vizsgálat elsődleges célja a tanfolyamra jelentkezők szürése volt (kizárólag kutatási céllal - gyakorlati következmény, azaz kizárás nélkül). Az alkalmazott tesztsor azonban lehetőséget nyújtott másodlagos adatelemzésre is az alább részletezett, speciálisan az érzelmekre vonatkozó nyolc kérdése révén. A tanfolyamra jelentkezők az elméleti oktatás megkezdése előtt kapták kézhez a kérdőíveket, melyek kitöltését egy moderátor segítette, ha az önálló válaszadás során megakadtak.

\begin{tabular}{|l|l|l|l|}
\hline \multicolumn{2}{|c|}{ fö } & \multicolumn{2}{c|}{ végzettség } \\
\hline \multicolumn{2}{|c|}{ nem } & általános & 6 \\
\hline nő & 205 & szakmunkásképző & 36 \\
\hline férfi & 34 & érettségi & 163 \\
\hline \multicolumn{2}{|c|}{ kor } & föiskola, egyetem & 26 \\
\hline 18-25 év közötti & 86 & nem válaszolt & 8 \\
\hline 26-35 év közötti & 63 & & \\
\hline 36-40 év közötti & 31 & & \\
\hline 40 év feletti & 54 & & \\
\hline nem válaszolt & 5 & összesen & 239 \\
\hline
\end{tabular}

1. számú tábla: A minta bemutatása

\section{KUTATÁSI EREDMÉNYEK}

A vizsgálat rávilágított, hogy a már problémásnak minősíthető 1,67 \% válaszadó mellett további 20 fő alaposabb vizsgálata lenne indokolt és őket a veszélyeztetett kategóriába sorolhatjuk - mivel 2-nél több kérdésre adtak igenlő választ. Tovább „bővül a kör”, ha azokkal is kívánnánk foglalkozni, akik akár egyetlen kérdésre is pozitív választ adtak (feltételezzük, hogy értelmezési, olvasási hiba is szerepet játszhatott) - utóbbi kategóriába összesen 47 fö $(19,66 \%)$ tartozik.

239 megkérdez etthöl veszélyeztetett és problémás játékosok aránya

12

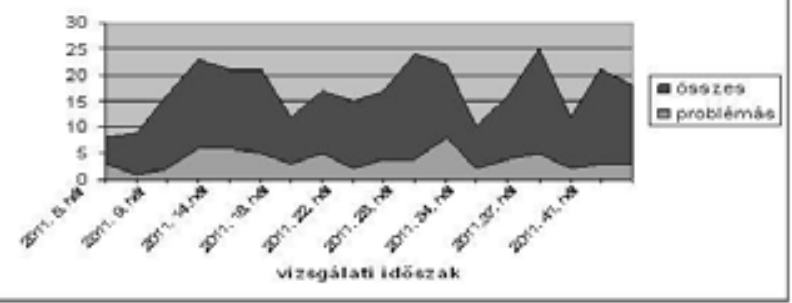

3.számú ábra: GA tesztek eredménye 2011-es szegedi szűrés alapján 


\section{Gamblers Anonymus 20-as tesztje}

1. Játszottál-e már a munkaidőd rovására?

2. Előfordult-e valaha, hogy a játék miatt vált gondterheltté az otthoni életed?

3. Érintette-e már a jó híredet a játék?

4. Éreztél-e valamikor lelkiismeret-furdalást a játék után?

5. Játszottál-e valaha is azért, hogy kifizethesd adósságaidat, illetve így oldd meg az anyagi nehézségeidet?

6. Gátolt-e a játék a törekvéseidben és abban, hogy hatékony legyél?

7. Vesztés után érezted-e azt, hogy minél előbb vissza kell menned, és visszanyerned, amit elvesztettél?

8. A nyerésedet követően éreztél-e erős késztetést arra, hogy minél többet visszanyerj, s még többet nyerj?

9. Gyakran elöfordul-e az, hogy eljátszod az utolsó filléredet is?

10. Kértél-e valaha kölcsön azért, hogy játszhass?

11. Adtál-e már el bármit is azért, hogy legyen pénzed játszani?

12. Előfordult-e hogy a mindennapi kiadások rovására szerettél volna „félretenni a játékra”?

13. Megtörtént-e hogy a játék miatt nem törődtél megfelelően önmagaddal vagy a családoddal?

14. Játszottál-e valaha hosszabb ideig annál, mint ameddig terveztél?

15. Játszottál-e már valaha azért, hogy így menekülj el az aggodalmaid és a gondjaid elől?

16. Tettél-e már valami törvénysértőt vagy fontolgattad-e, hogy teszel, hogy pénzt szerezhess játékra?

17. Zavarta-e a játék az alvásodat?

18. A veszekedések, csalódások vagy feszültségek arra késztettek-e, hogy játssz?

19. Érezted-e már azt, hogy bármi jót, ami csak ért, játékkal kellene megünnepelned?

20. Gondoltál-e már arra, hogy tönkremehetsz játék következtében?

1. számú melléklet: Gamblers Anonymus teszt

A vizsgált mintánkban tehát $71,5 \%$ tekinthető teljes egészében - a válaszaik alapján - probléma mentesnek a szerencsejátékokhoz való viszonyulásukat tekintve. A feltett 20 kérdés közül érzelemre kérdez rá a 2. 4. 7. 8. 15. 17. 18. és 19. kérdés. Ha a veszélyeztetett és problémás kategóriába sorolt szereplők ezen válaszait külön is megvizsgáljuk, akkor 28 válaszadó adott igenlő választ, közülük 10 több kérdésre is. Tehát a teljes vizsgált sokaság 11,7 \%-a „érintett érzelmileg", a problémás és veszélyeztetett válaszadók 41,17\%-a ezen kérdésekre adott válaszai miatt „akadt fenn” a szűrőn. a 4. számú ábra az első vizsgálati körben kiszürt problémás és veszélyeztetett szerencsejátékosok érzelmeikre vonatkozó kérdésekre adott pozitív és elutasító válaszai alapján való elkülönítését mutatja be - az érzelmeikre vonatkozó pozitív válaszok számaival.

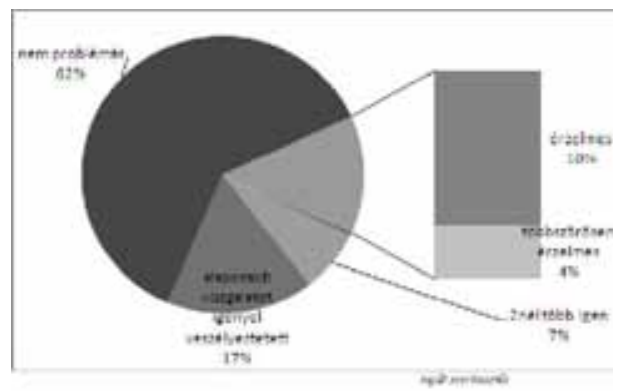

4.számú ábra: A problémás és veszélyeztetett játékosok „érzelmi" viszonyulása
A kereszttábla elemzések és a szignifikancia értékeket az 5. számú táblázatban csatoljuk. A táblázatban az első oszlop a játékos típus szerinti megoszlásokat és elemszámokat tartalmazzák. A negyedik oszlop pearson-chi square szignifikancia értékei a konkrét Khí-négyzet teszt eredményei. Azért ezt alkalmaztuk, mert kategorikus változók közötti kapcsolatot vizsgálunk. Mindenütt a sig<0,05 értékek alapján a teszt nullhipotézisét - jelen esetben: a játékos „típusa” és az érzelmes kérdések között nincs kapcsolatot - elvetjük, azaz a játékos típus és az érzelmes kérdések között van kapcsolat. A táblázat utolsó oszlopában a Cramer $V$ értéke (value oszlop), a kapcsolat erősségét fejezik ki. Majdnem mindegyik esetben közepes erösségű kapcsolat mutatható ki a játékos típusa és az érzelmes kérdések között (a mutató 0,5-höz közeli értékei alapján).

\begin{tabular}{|l|l|l|l|l|}
\hline & \multicolumn{2}{|l|}{$\mathrm{N}=210$} & & \\
\cline { 2 - 5 } & $\begin{array}{l}\text { veszélyez- } \\
\text { tetett }\end{array}$ & $\begin{array}{l}\text { problé- } \\
\text { más }\end{array}$ & szignifikancia & value \\
\hline gondterheltség & 2 & 6 &, 000 &, 515 \\
\hline lelkiismeretfurdalás & 9 & 8 &, 000 &, 543 \\
\hline többet nyerni & 4 & 8 &, 000 &, 572 \\
\hline veszekedés & 1 & 0 &, 128 &, 140 \\
\hline ünneplés & 14 & 7 &, 000 &, 561 \\
\hline
\end{tabular}

2. számú táblázat: 210 válaszadó érzelmi érintettsége a kiemelt vizsgálati szempontok alapján 
Három kérdés esetén (8., 15. és 17. kérdések) nem volt elvégezhető a teszt, mert csak nemleges válaszok jöttek az adott érzelmes kérdésekre.

A vizsgált mintánkban tehát a veszélyeztetettségi szint elérésében is szerepet játszott az izgalom, ebből kifolyólag a szenvedélyes szerencsejáték függők esetén is szignifikáns kapcsolat mutatható ki az izgalom és a függővé válás között. Következtetések

Az izgalom kérdésköre nemcsak az egyes játéktípusok veszélyességének mérhetősége miatt érdekes, hanem a játékos, fogadó oldaláról történő megközelítés esetén is, hiszen ennek egyértelmü kalibrálásával pontosabb képet kaphatunk arról, hogy ez a kevéssé racionálisnak tekinthető magatartásforma miként is alakul ki. Vizsgálatunk alapján a szerencsejáték szenvedély szempontjából érintett (problémás vagy veszélyeztetett kör) közel fele érzelmei által determináltan sorolható ebbe a kategóriába.

Önmagában már arra is nehézen találhatunk racionális magyarázatot, hogy a szerencsejátékos tevékenységek bizonyos formái miért is mozgatják meg az embereknek ekkora tömegét, és gazdasági értelemben is miért ilyen jelentős az erre fordított összeg. A pszichológiai vonatkozások, úgymint az izgalom kérdéskörének körüljárása is segíthet ennek megértésében.

Diagnosztikai szempontból a már beazonosított, problémás játékosokkal szokás foglalkozni, az ő kezelésük mikéntje és egyes prevenciós intézkedések szükségessége merül fel. Viszont közel tízszeres azok száma, akik még „csak súrolják” a határt, azaz veszélyeztetettek. Egy másik vizsgálat tárgya lehet az ő életkori megoszlásuk, játék fajtánként különböző számosságuk és az egészséges játék keretei közt tartásuk mikéntjének kutatása.

\section{IRODALOMJEGYZÉK}

»Blaszczynski, Winter és Neil McConaghy (1986): Plasma endorphin levels in pathological gambling; Journal of Gambling Studies Volume 2, Number 1, 3-14.o.

» Barkan, Rachel és Jerome R. Busemeyer (2003) : Modeling Dynamic Inconsistency with a Changing Reference Point, \& Framing reference points: the effect of integration and segregation on dynamic inconsistency; Journal of Behavioral Decision 16(4):235 - 255.o.

» Becker, G.S. és Murphy K.M. (1986): A theory of Rational Addition; Working Paper no.41. Chicago: University of Chicago » Dickerson, M. G., Hinchy, J. és Fabre, J. (1987) : Chasing, arousal and sensation seeking in off-course gamblers, British Journal of Addiction, 82, 673-680.o.

»E. B. Andrade és G. Iyer (2007): Dynamic Inconsistencies in Gambling and the Role of Feelings; Haas Business School Working Paper
» Elster, Jon (2000): Alchemies of the Mind: Rationality and the Emotions; Cambridge University Press

» Fehr (2005): Mit Neuroökonomik das menschliche Wesen ergründen Nach der Psychologie ziehen Wirtschaftswissenschafter die Biologie zu Rate, Neu Zürcher Zeitung No.146

" Faragó Klára (2003): Etikai kérdések a gazdaságpszichológiában Osiris in Hunyady-Székely: Gazdaságpszichológia, Bp, »Freund Tamás (2007): A belső kannabinoid jelzés, mint szinaptikus biztosíték neurológiai betegségekben in: Jakabffy Éva (2009): Új hírvivő rendszer A belső kannabinoid jelzés Természet Világa, 140. évfolyam, 4. szám, From: http://www. termeszetvilaga.hu

" Gamblers Anonymous's Twenty Questions (2005.) (the GA20) (Gamblers Anonymous)

» Griffiths (1999): Gambling technologies: Prospect for problem gambling; Journal of Gambling Studies 15, 265-283.o.

"Sinha (2004): Factors Contributing to the Development of Pathological Gambling From: http://www.personalityresearch. org/papers/sinha.html

"Nower, Derevensky és Gupta (2004): The Relationship of Impulsivity, Sensation Seeking, Coping, and Substance Use in Youth Gamblers; Psychology of Addictive Behaviors Vol. 18. No. 1. 49-55.o

» Lightsey, O.R., és Hulsey, C.D. (2002): Impulsivity, coping, stress, and problem gambling among university students; Journal of Counseling Psychology, 49(2), 202-211.

" Lippai László (2011): Az önkontroll szerepe és jelentősége az intertemporális fogyasztói döntésekben - Doktori értekezés Szegedi Tudományegyetem, Gazdálkodástudományi Doktori iskola

" Loewenstein, G.(1987): Frames of mind in intertemporal choice, Management Science, 34, 200-214.o.

» M. Rabin (2008): Pszichológia és közgazdaságtan; Alinea Kiadó - Rajk László Szakkollégium

" M. Zuckerman és S. R. McDaniel (2003): The relationship of impulsive sensation seeking and gender to interest and participation in gambling activities; Personality and Individual Differences, Volume 35, Issue 6, 1385-1400.o.

" Mark D. Griffiths and Richard T.A. Wood (2000): Lottery gambling and addiction: An overview of European research Psychology Division 1-11.o.

" Mark D. Griffiths and Richard T.A. Wood (2007): A qualitative investigation of problem gambling as an escape-based coping strategy; Psychology and Psychotherapy; Theory, Research and Practice 80, 107-125.o.

» Mimi Larsson (2006): Az idősebbek bekapcsolódása az információs és kommunikációs technológiák alkalmazásába a gyakorlatban; WIP Mapping the Digital Future. Budapest » Ricketts T.; Macaskill A. (2003): Gambling as emotion management: developing a grounded theory of problem gambling; Addiction Research and Theory, Volume 11, Number 6, 383400.0. 